原著

\author{
外傷性小腸穿孔症例の臨床的検討
北里大学救命救急医学（主任：大和田 隆教授）
杉本勝彦前川和彦今井恒
同 外科（主任：阿曾弘一教授） \\ 島 津 盛一
}

北里大学病院救命救急七ンター及び外科で経験した，外傷性小腸穿孔74症例について 臨休的に検討を行った，受傷機転は，半数以上が交通外傷であり，大部分が多発外傷で あった。本損偒の診断は，特に，意識障害症例や，多発外傷症例で困難であった。補助 診断法の中で腹部単純 $\mathrm{X}$ 線写真, 腹部エコー、CTはその診断能力に限界があった。診 断的腹腔洗浄法は，特にその腹部症状が明らかでない多発外偒症例で有用な検査法で あった，死亡率は1.4\%であったが，㭪後合併症の頻度は $40 \%$ 代と高率であった。問題と なった㭪後の感染性合併症発症の最も重要な要因としては, 受傷から手術開始むでの治 療時間の遷延であった。

索引用語：腹部外傷，小腸穿孔，診断的腹空洗浄法，腹部外傷の画像診断

\section{緒 言}

外傷性小腸破裂は，鈍的外傷の多い本邦では，比較 的上く遭遇する腹腔内䒽器損䅉の一つである。消化性 漬湯穿孔ゃ虫垂炎穿孔なとの穿孔性腹膜炎を报い慣れ ている一般外科医にとって报いやすい外傷ですある。 近年, 生活様式の多様化や高層化, 交通手段の高速化 なとに伴い外傷患者の損傷形態は複雑化し，多発外偒 患者が増加してきている゙，単独缄器損倁患者に比べ て，損偤が多葴器系に及ぶ多発外傷患者では，明らか な他の㼨器損傷に隐暼されて，ともすると腹腔などの 閉鎖体腔内の臟器損傷の診断々治療が遅延し、患者の 予後を增悪させることがある゙!。らした視点にたっ て，今回，外傷性小腸破裂の䛦断と治㞠の問題点につ き検討したので，文献的考察を加えて報告する。

対象及び方法

1981年 4 月が51987年 3 月迄の 6 年間に北里大学病院 救命救急センター及び外科で扱った外傷性小腸破裂・ 穿孔症例を検討の対象とした。この期間中に腹部外傷 で開腹術を受けた症例312例中，外傷性小腸破裂・穿孔 は74例 $(23.7 \%)$ で，外傷性小腸破裂・穿孔症例は全 例開腹手術を受けた，受傷機転は58例 $(78 \%)$ が鈍的 外傷であり，交通外賃に起因するあのが全体の $52 \%$ を

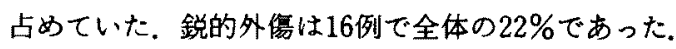
年龄分布では10代か560代までが 62 例 $(83.7 \%)$ で， 活動的な青壮年層に王倒的に多くみられた，男女比で は，女性 7 に対して男性67と男性に多い傾向であった (表 1).

小腸の破裂穿孔部位は，Treitz 靬帯もしくは回腸末 端部付近の小腸固定部近傍に多く, Treitz 勒帯及び回 腸末端部か $51 \mathrm{~m}$ 以内のものが52例 $(70.2 \%)$ と大半を 占めていた。これらの症例の内, 腹腔外脸器損傷を合 併していたのは38例（51.4\%）で，小腸損傷に腹腔外 藏器損傷を合併している多発外傷症例がやや多い㑯向 にあった，合併する腹腔内蔵器損傷では小腸に隣接す る腸間膜損傷が17例と最も多かった（表 2 ）.

これら手術を受けた74例の小腸破裂・穿孔患者につ いて, 診断, 手術適応, 術式, 術後合併症及び予後に ついて検討した，特に術後合併症の内，創感染，術後 イレウス，腹䐁内膿瘍については，それぞれの合併症 を起こさなかった症例を対照群として，受傷から手術 開始迄の所要時間, 破裂穿孔部位, 術中腹空洗浄量, 腹腔ドレナーシの有無, 術前抗生物質投与の有無、細 菌培養, 受傷機転, 腹腔内他臓器合併損傷などによる 差, あるいは相関の有意性を $\mathrm{t}$ 検定または $\chi^{2}$ 検定を用 いて検討した.

昭和63年 2 月 24 日受付 63 年 7 月 29 日採用 


\section{表 1 外侮性小渴破裂74症例の背罴}

$n=74$ 例 $(74 / 312: 23.7 \%)$
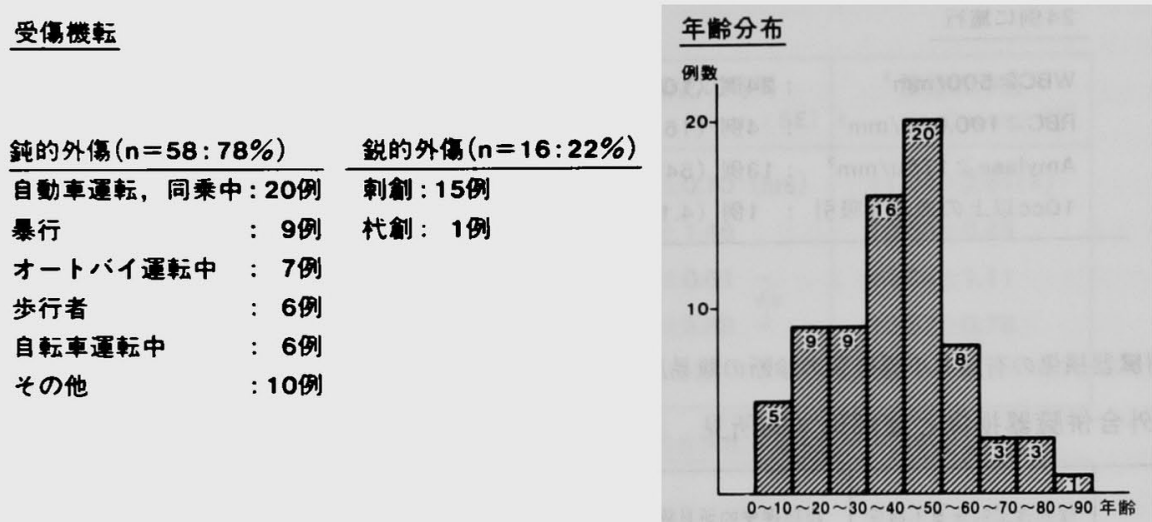

表 2 小腸の破裂・穿孔部と合併䑏器損稘 小蜮穿孔、破裂部位の分布

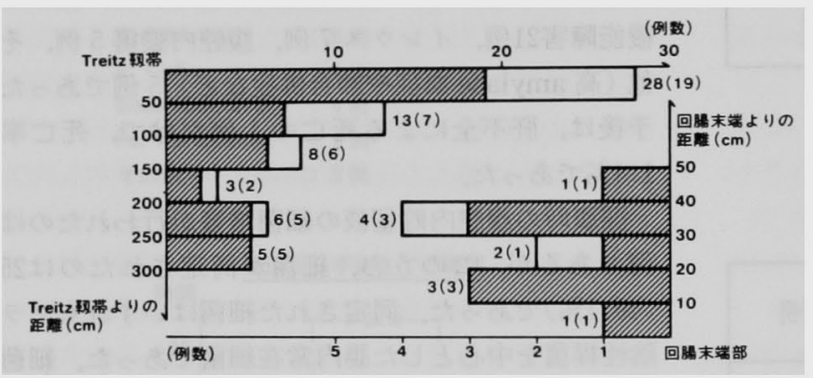

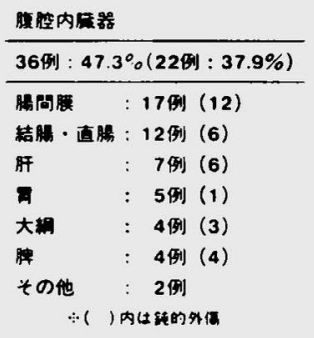

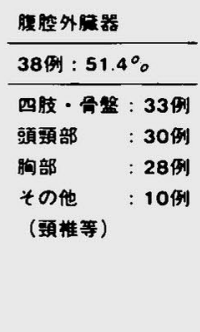

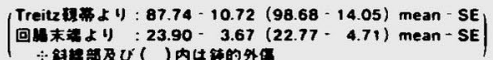

\section{結果}

\section{1. 診断}

手術前に筋性防御，反跳痛などの明らかな腹膜刺激 症状を呈していたすのは53例（71.6\%）であった。入 院時の腹部単純レントゲン写真で, 腹腔内遊離ガス像, dog's ear signなど何らかの異常所見を示したものは 33例（44.6\%）にすきなかった.

画像診断法の内, 腹部超音波検查法(以下腹部ェュー と略す), コンピュータ断層撮影(以下 CT と略す)は, 腹部エコーが10例に, CTが7例に行われ,それぞれの 診断陽性率は $45.5 \%$ ，70\%であった。

診断的腹腔診断法 (diagnostic peritoneal lavage : 以下 D.P.L. と略す) は24例に行われ, 全例で手術適応 となる陽性所見を得た。

D.P.L. は確定診断に迷った 24 例 $(32.4 \%) に$ 行われ

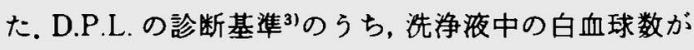
$500 / \mathrm{mm}^{3}$ 以上であったものは全例であったが, amylase 値が診断基準を満たするのは13例（54\%）に 過ぎなかった。腹部ェコーを施行した内の 6 例と CT を施行した内の 5 例で, 腹腔内液体眝留等の異常所見 を証明できたが，その性状を確認する為に D.P.L. が追 加施行された（表了）.

他の缄器系損傷を有していた症例群と腹腔内葴器損 傷のみの症例群の間で, 小腸破裂の診断の難易度を検 討した. 腹部理学的所見が明らかでないか, 診断に迷っ た症例を腹部理学的所見不確定として比較すると, 他 の蔵器系損傷を有する症例群では, 有意に診断に迷う 症例が多かった $(p<0.01)$. 又, 確定診断の為に行っ た D.P.L. 施行症例も, 有意に他の缄器系損傷を有して いた群でより多く行われていた（p<0.01）（表 4). 


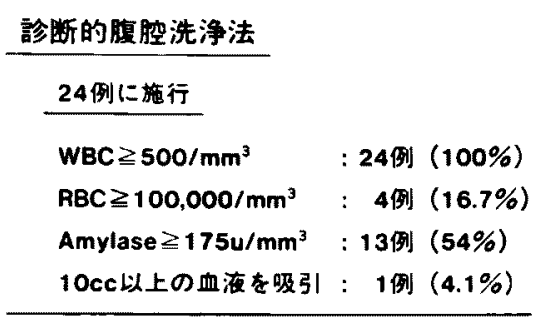

表 4 合併搭器損稘の有無と小腸破裂の診断の難易度 腹腔外合併荿器損傷と腹部理学的所見

\begin{tabular}{|c|c|c|}
\hline & 䧗部理学的所見不碓定 & 腹部理学的所見陽性 \\
\hline 合併䑏器損稘 (一) & 3 (例) $]_{*}$ & 33 \\
\hline 合阱監器損鹪 (+) & 18 & 20 \\
\hline
\end{tabular}

腹腔外合併脿器損偒とD・P・L施行例

\begin{tabular}{|c|c|c|}
\hline & $D \cdot P \cdot L$ 非旅行例 & $D \cdot P \cdot L$ L施行例 \\
\hline 合伴嚾器損傷 (一) & 30 (例) & 67 * \\
\hline 合併嚚器損傷 $(+)$ & 20 & $18^{]}$ \\
\hline
\end{tabular}

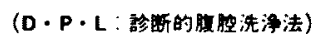

*: $X^{2}=8.88462 \quad P<0.01$

\section{2. 治療}

受傷より治療開始までの時間は，最低 3 時間から最 高72時間までで，平均 8 時間30分を要した。手術方法 は，1例を除いて穿孔部位の単純縫合閉鎖と，部分切 除と端端吻合の 2 群に大別された， 1 例は，非代偵性 の訮硬変应例で，肝不全による腹水詝留が多量に認め られ，受鹪から手術開始まで長時間を要していた為, 释合不全を懸念して exteriorization が行われた. 又, 多発外倁症例で同時他部位手術が行われたるのは24例 あり,この内他の主要臓器損傷の手術が先行したbの
他の補助钐断法の陽性事

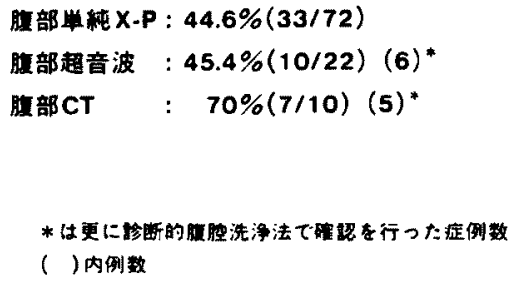

は20例，小腸破裂の治療が先行したるのは 4 例であっ た。

受傷から治㞠開始までの時間が透延した症例 (mean $\pm \mathrm{SE}, 13.25 \pm 3.89)$ では，腹腔ドレナージか行 われた（表 5 ).

\section{3. 術後合併症}

術後合併症は，34例（45.9\%）に認められた，その 内訳は創感染が25例 $(35.1 \%)$ と最も多く，次いで肝 機能障害21例，イレウス 7 例，腹腔内膿煬 5 例，その 他（高 amylase 血症や肺合併症など） 5 例であった。

予後は，盰不全による死亡の1例たけで，死亡率は $1.4 \%$ でった。

開腹時の腹腔内眝留液の細菌培羲が行われたのは51 例であるが，このうち，細菌が同定されたのは25例 (49.1\%)であった。同定された細菌はいずれもクラム 陰性桿菌を中心とした腸内常在細菌であった．細菌が 検出された症例とされなかった症例との間で，手術迄 の時間を比較すると，細菌が同定された群では，同定 されない群より明らかに長かった（15.00土3.60時間 vs $5.25 \pm 0.54$ 時間：mean $\pm \mathrm{SE}, \mathrm{p}<0.05)$. しかし, 腹腔内貯留液の細菌培養が陽性か否か心，小腸破裂穿 孔部位と無関係であった（表6）。

創感染合併群を創感染を起こさなかった症例を対照 群として, 手術迄の時間, 術中腹腔洗浄量, 穿孔破裂 部位，紐菌培䖯陽性率，腹腔ドレナージ，術前抗生物 質投与の有無、及び腹腔内他缄器合併損傷の有無で比 較した，創感染合併群では，受傷より手術迄の時間が 対照群に比べて明らかに長かった（12.99土3.1時間 vs $6.11 \pm 0.61$ 時間：mean士SE，p<0.05)，腹腔洗净量， 破裂穿孔部位については明らかな関連を認めなかっ た，又，細菌培盖陽性症例では，之細菌培羡陰性症例 に比べてょり創感染を起こしやすい事が示された $\left[x^{2}=12.9214(\mathrm{p}<0.01)\right]$.

受傷機転, 腹腔ドレナージ，術前抗生物質投与，腹 
表 5 外但性小腸破裂の治療

受稘より手術迄の時間 : 3〜72hrs. (8.50 \pm 1.35$)$ mean $\pm S E$

\begin{tabular}{|c|c|c|c|}
\hline 手 街方 法 & 例 数 & $\begin{array}{c}\text { 手雨迄の時間 } \\
\text { (mean } \pm \text { SE) }\end{array}$ & $\begin{array}{l}\text { 璄腔洗浄量 } \\
\quad(\text { mean } \pm S E)\end{array}$ \\
\hline Debridement + 合閉褰 & 21 & $6.52 \pm 0.70$ (hrs) & $11.04 \pm 2.61(\ell)$ \\
\hline Debridement + 合閉基+ドレナーシ & $9(6)^{*}$ & $7.73 \pm 1.46$ & $10.00 \pm 0.45$ \\
\hline 部分切除十端々昒合 & 19 & $4.99 \pm 0.61$ & $14.34 \pm 1.11$ \\
\hline 部分切除十端々略合+ドレナーシ & $24(15)^{*}$ & $13.25 \pm 3.89\lrcorner$ & $13.87 \pm 0.78$ \\
\hline Exteriorization+ドレナーシ & 1 & & \\
\hline & \multicolumn{3}{|c|}{ *(）内は他酸内合併症の为ドレナーシを行った症例。 } \\
\hline & \multicolumn{3}{|c|}{$* * P<0.05$} \\
\hline
\end{tabular}

表 6 腹腔内眝留液の細菌培意に閉する因子の解析

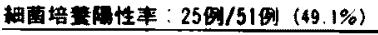

\section{同定西種}

$\begin{array}{ll}\text { Str. fecalis } & : 8 \text { 例 } \\ \text { E. Coli } & : 7 \text { 例 } \\ \text { Enterobacter } \mathbb{R} & : 4 \text { 例 } \\ \text { Ps. Aeruginosa } & : 3 \text { 例 } \\ \text { その地 } & : 3 \text { 例 }\end{array}$

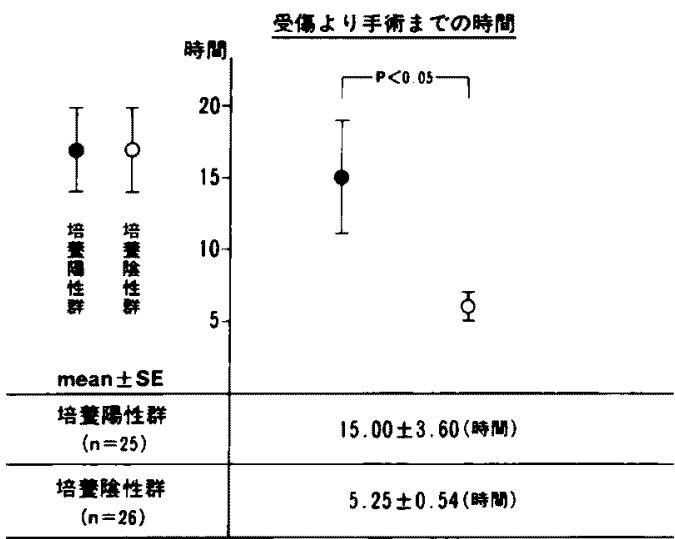

腔内他臟器合併損傷と創感染との間には明らかな関係 は認められなかった（表７）。また術後腹腔内膿境，及 びイレウスの合併は, 手術迄の時間, 術中腹腔洗浄量, 穿孔破裂部位，細菌培善，術後腹腔ドレナージ，術前 抗生物質投与, 腹腔内他藏器合併損伤の存在のいずれ とも明らかな関係は認められなかった。

$$
\text { 考案 }
$$

外傷性小腸破裴・穿孔の診断は，腸管内容の腹腔内
表 7 創感染発生に関する因子の解析

\begin{tabular}{|c|c|c|}
\hline & 吅感染症例 & 非感染例 \\
\hline 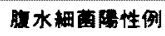 & 16 (x) & 9 \\
\hline 胶水細薄㓌性洌 & 9 & 40 \\
\hline
\end{tabular}

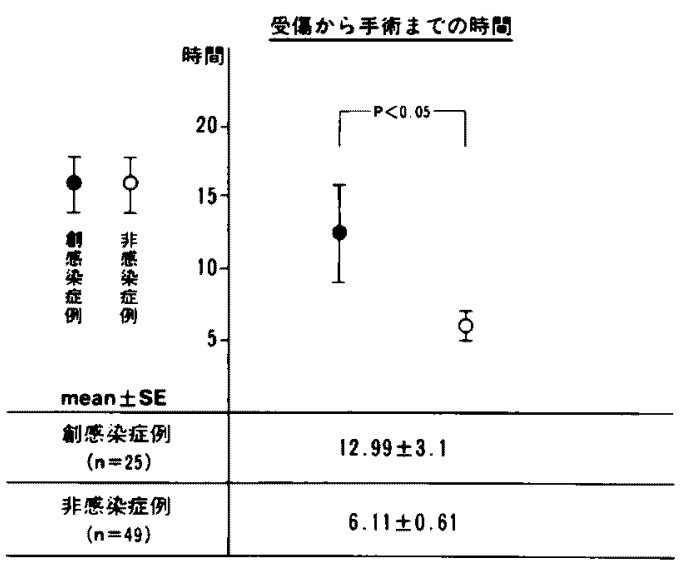

への漏出による腹膜炎の為に，腹膜刺激症状が比較的 早期より出現し，腹部理学的所見のみで可能である事 が多い，その予後は一般には，重篤な感染性合併症を 併発することもなく，良好であるとされている゙，一 方，手術時期の遅れた症例では，重篤な感染性合併症 により、死亡率は30\%から50\%に及ぶ45)．腹膜炎によ る腹膜刺激症状が明らかで，診断が比較的容易である はずの外賃性小腸穿孔が問題となるのは，頭部，胸部 などの，他缄器系損傷を同時に有する所謂多発外傷患 
者の場合である。多発外傷患者では，低容量血症や vital organの機能不全をむたらす主損傷に対する診 断と治療が最優先され，直ちに vital signに変化をる たらさない小腸穿孔は見過ごされてしまう，又，al chol, 薬物等の影響による意識障害, 頭部外偒や春䯣損 智，骨盤骨折や胸部などの他部位の疼痛等を有する多 発外䧼患者などでは，腹膜刺激症状を正確に把握し難 く,診断に迷ら事もある。時代背景の变䙴々共に，様々 な受傷機転によりその損傷形態が复雑化してきてい る。これにつれて，単一䁍器損偒よりる多発外傷患者 の頻度が増加する傾向にある，外傷性小腸穿孔が多発 外傷の一分症として取り报われる頻度は増加し，診断 困難な小腸穿孔症例が増加するかむ知れない，われわ れの症例でも, 小腸単独損傷例上り小腸破裂に他臓器 損傷を合併した多発外傷患者の頻度のほうが多く，腹 部理学的所見のみで手術適応が決定され得なかったも のは，明らかに多発外甥患者のほうに多かった，腹部 理学的所見を正確に把握し得ない症例では，何時でも， 何処でも，又誰にでも行えるような，簡便でかつ再現 性のある正確な補助猃断法が必要となる。

画像診断法の1つで，最す一般的に，よく行われて いる腹部単純 X 線写真では，外傷による消化管穿孔を 裹付けるよ5な腹腔内遊離ガ像の出現頻度は, Robbs $^{5}$ や，Ting ら》の報告でも50\%以下と低く， Root ら8)同し理由で確定診断には不適当であるとしてい る。われわれの倹討でも，dog's ear sign，傍結腸溝の 開大などの間接所見を加之ても明らかな異常所見の陽 性率は40\%程度であり，手術適応決定のための補助診 断法としては不充分であると考劣られた。

近年飛躍的な進歩と普及を見だ画像診断学の中で， 腹部エュー, CT, 血管造影などは外傷外科領域にも皘 極的に取り入れられてきている。実質藏器損傡や腹腔 内出血の経時的変化を非侵襲的比何度でも繰り返し観 察することにより，活動的な出血が見られない実質臓 器損賃の不必要な開腹術を回避し，更には活動的な出 血が持続する臟器損傷に対して interventional radiology の応用により止血を計り，単に臟器損傷の診断 たりでなく損傷缄器の積極的な保存的療法が行われる よ5にもなってきている21 12)，一方，管腔臟器損傷に ついては，CT や腹部エコーによる彰断の試みの報告 があるが未だ一般的ではない(13144.われわれの症例で， 腹部エコー, CT を行い, 腹腔内液体眝留や腸間膜の腫 大等の異常所見を示したわのああったが，消化管穿孔

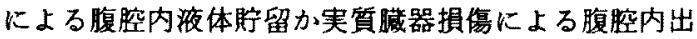

血かの判断は腹部エコー- CT だけでは困難で, 更に他 の補助診断法により啠的猃断を行う必要があった。腹 部ェコー，CTは非侵襲的に何度でも繰り返し行う事 ができ，病変の変化を経時的に観察できる利点がある が, 機器の操作, 結果の判断に施行者の技能が影響し たり，CTでは放射線科医に依存する部分が大き，何 時でも，かつ又誰にでも行える補助部断法としてはを の条件を满たしていない。

1965年. Root 5 ${ }^{15}$ によって開発され，臨床的に応用 されてきたD.P.L. は最も簡便な方法として今日でる 欧米では腹部外傷の診断に用いられ評価を得てきてい

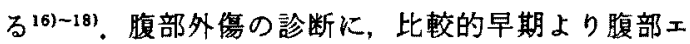
コー, CT 等の画像診断法の導入が行われた本邦では, D.P.L. は腹腔内出血に対して sensitivity が高過ぎる との批判があり ${ }^{199}$ ，腹部外傷の診断における役割につ いての報告は少ない，実質臟器損鹪に対する保存的療 法が注目を集めてきている今日，腹腔内出血の存在の 確認には有用であるが定量的特性を欠く D.P.L.は，腹 部外傷の診断法として否定的な意見さえ見られる ${ }^{20)}$. しかし，管腔藏器損傷や消化管穿孔等の腹膜炎状態に 対しての D.P.L.は，諸家の報告をみても，その診断率 は95\%以上と高く，上記の画像診断法と比較しても䢞 色のない診断能を有している16) -18)，われわれの小腸穿 孔症例でも，腹部理学的所見や他の検查法では，損傷 の存在が明らかでなかった24例に D.P.L.が行われ，全 例飞陽性所見を認め，偽陽性症例は無かった，外科医 であれば，簡単な器具を用いて何時でわ何処です出来 る方法として, 診断的腹腔洗浄法は外傷性小腸穿孔に 対しても有用な補助診断法の 1 つである.

一般的には，大腸などの下部消化管の場合に比較し て，小腸を含む上部消化管穿孔の予後は比較的良好て ある。この事は，上部消化管では嫌気性菌をはじめと して腸内常在菌の絶対数が少ない為に, 管腔内容漏出 による腹膜炎を起こしても重篤な感染性合併症に陷り にくい為であるとされている゙121. Thadepalli らは、生 理的な条件下では，小腸内の常在細菌は殆ど存在しな いが，腹部外傷等により消化管蠕動の低下している状 態では，時間の経過とともに，小腸内細菌は嫌気性菌 を含むようになり，十二指腸付近まで有意に增加する と報告している22128．又，受傷後開腹術主での時間か， Carswell ら5゙よると受傷後12時間, Robbs ら"は24 時間以上遷延すると，重篤な感染性合併症により，そ の死亡率は $50 \%$ 近くまで上昇する。開腹時に行った腹 腔内貯留液の細菌培養では，症例の50\%近くで細菌が 
司定されたが，いずれも開腹術迄の時間が10時間以上 垔延した症例で，これらの報告を裏付けるものであっ た. 又、術後合併症のなかで最も多かった創感染は， 開腹までの時間が遷延した症例に多く，受傷後 8 時間 以内に開腹街が行われた症例では創感染は問題となら なかった。

小腸破裂の治療は、手術による修復が基本であるか， 損傷形態により創の単純縫合か腸切除による端端吻合 が行われる，損傷部周囲組織の挫隇や循環障害が無い 易合には単純縫合閉鎖が，周井組織の挫減がある場合 には，周囲組織の debridement 後，長軸と直角方向に 䋖合閉鎖する，腸切除に上る端端吻合は，腸管全周に わたる高度な挫隇，腸間膜損傷を伴 5 部分的な循環障 害，一定の範囲内に破裂部位が多発し，それぞれを縫 合するより切除・吻合したほらが安全で容易であると 判断された場合などである，吻合法は，通常 AlbertLembert 法による結節䋖合で，端端吻合を行い小腸の 狭窄を防ぐようにする，小腸は管腔臓器の中でも最む 血流が豊富な缄器で、これらの方法でその治瘾は十分 に期待できる24. 特殊な場合, 例えば著しい腹膜炎やそ の他の理由で吻合部の縫合不全が強く懸念される時な どでは，大腸損傷の治療に選択される吻合部分の腸管 を腹膜外に留置する exteriorizationが行われること がある25). われわれが経験した非代償性肝硬変の症例 に exteriorizationが行われたが最終的に縫合部は縫 合不全をおこした。

感染性腹膜炎に対して行われる術中の腹腔洗净は 1905年Price ${ }^{261}$ により提唱されて以来, 今日まで広く 用いられてきている吕-29! . 大量の生理的食塩水で腹腔 内洗浄を行うことにより、腹腔内細菌数を减少させて, 㭪後の感染性合併症や予後の改善を期待しようとする るのである．洗净に用いる生理的食塩水の量は，4５ Lが適当で，10L 以上では細菌の絶対数は变化しない とされているが,倉光らは患者の体重当たり最低 $200 \mathrm{cc}$ が必要であるとしている21.われわれは，最低10L 以上 を基準として洗浄を行った.しかし，10L 前後の洗浄で は, 術㣪に合併症を起こした症例もあり, 洗浄量や， 洗浄液内の抗生物質の添加，創管理などを今後更に検 討すべきであろ5。

一般に, 腹腔内が污染されている腹膜炎の場合には, 左右横隔膜下, ウインスロウ孔やダグラス窝等に, 膿 汁や，出液のドレナージを計るためにドレーンの插 入が行われる。腹腔ドレナージには，逆に創感染や逆 行性感染等の合併症が増加するとして, 反対意見もあ
る28)301. 外傷性小腸穿孔症例についても, 腹腔ドレナー シが必要であるとい5意見もあるが25)，山本”や渡辺 等 ${ }^{31}$ 恃基本的に小腸穿孔の場合、腹腔ドレナージは必 要ないとしている。われわれの症例でも，腹腔ドレナー シと術後の合併症との間に明らかな関係は認めていな い. 術中の十分な腹腔洗浄が行われれば，小腸穿孔の 䋖合部や吻合部の治空過程は極めて良好であり，膿瘍 形成はなく，特殊な場合を除いては基本的には，外傷 性小腸穿孔には腹腔ドレナージの必要性は無いと思わ れた。

一般的に, 外傷患者の主要死亡原因は, 重症頭部外 傷と大量出血によるショック，晚期合併症の敗血症 ${ }^{321}$ である。われわれの症例では, 重篤な他合併满器損傷 や頭部外傷が少なく，致命的な感染性合併症的起こさ なかった為, 死亡症例は, 非代償性肝硬変症例の肝不 全による1例たけであり，受傷から手術までの時間か 遷延した症例も含めて，その予後は良好であった，外 傷性小腸破裂症例の予後は他缄器損偤症例之比較して も良好であるが，徒後合併症の頻度は依然として高率 である。早期診断による治療開始時間の短縮が術後合 併症の防止には最む重要であり, その為には腹部症状 が明らかでない小腸穿孔症例，特に多発外傷症例に対 する，診断的腹腔洗浄法を中心とした診断の積極的な フプローチが必要と考えられた。

\section{結 語}

外傷性小腸穿孔74症例の診断, 治療及び予後につい て臨木的に検討し，以下の結論を得た。

1）小腸単独損傷上り多発外傷症例のほうが多く、多 発外傷症例では腹部理学的所見が不明確なもの゙多 かった。

2）腹部単純 $\mathrm{X}$ 線写真, 腹部エコー, CT は手術適応 決定の為の補助診断法としては限界があった。

3）補助診断法では診断的腹腔洗浄法が有効であっ た.

4）術後合併症では創感染が問題となった。

5）治療開始の遅れが術後創感染合併の最も大きな 要因である.

6）術後合併症の防止には，早期診断と手術及び徽底 した術中の腹腔洗浄が肝要であり，腹控ドレナージの 必要性は認めなかった。

7）外傷性小腸破裂症例の予後は良好であった。

尚, 本論文の要旨は第 49 回日本臨床外科医学会総会, 福岡 にて報告した。 


\section{女 献}

1）山本管三：腸管，四方淳一，外科 Mook, 腹部外伤 （17），金原出版，東京，1980，p138-147

2) 前川和彦：多発外侮, 治療 $64: 85-89,1982$

3) Anderson $C B$, Ballinger WF : Abdominal Injuries, GD, Zuidema, RB, Rutherford, WF, Ballinger, The Management of Trauma (4), WB, Saunders, Philadelphia, 1985, p449-504

4) Christensen N: Small Bowel and Mesentery, Blaisdell \& Trunkey, Trauma Management, (1), Thieme-Stratton, New York, 1982, pl49 $-163$

5) Robbs JV, Moore SW, Pillay SP: Blunt Ab. dominal trauma with jejunal injury: A review. J Trauma $20: 308-311,1982$

6) Carswell JW: Small bowell injuries in blunt abdominal trauma. Injury $5: 233-236,1974$

7) Ting YM, Reuter SR: Hollow viscus injury in blunt abdominal trauma. Am J Roentgenol 119 : $408-413,1973$

8) Root HD: Hollow visceral injuries. $M$ Cleveland \& S. Wolferth, Advances in Trauma (2), Year Book Medical Publisher, 1987, p163 $-178$

9）横田順一郎, 造谷正徳, 橋本公昭他：肝損甥の画像 診断，救急医学 $10: 685-697 ， 1986$

10) Federle MD, Crass RA, Jeffiry RB, et al : Computed tomography in blunt abdominal trauma. Arch Surg 117:645-650, 1982

11) Goldstein AG, Salvatore JA, Scalafani TA, et al: The diagnostic superiority of computed tomgoraphy. J Trauma $26: 660-665,1984$

12）前川和彦：腹部外傷診断のポイント, 臨画像 2 : 8-13, 1986

13) Donohue JH, Federle MP: Computed tomography in the diagnosis of blunt intestinal and mesenteric injuries. J Trauma $27: 11-17,1987$

14）金田衛：管腔缄器損傷の画像診断, 救急医学 $6: 675-684,1986$

15) Root HD, Hause GW, Mckinley $C R$, et al: Diagnostic peritoneal lavage. Surgery $57: 633$ $-636,1965$

16) Fisher RP, Bervelin BC, Engrav LH, et al: Diagnostic peritonal lavage. Am J Surg 136 : 701-704, 1978

17) Gomez GA, Alvarez R, Plasencia G, et al : Diagnostic peritoneal lavage in the manage- ment of blunt abdominal trauma: A reassess ment. J Trauma $27: 1-5,1987$

18) Danto LA: Parecentesis and Diagnostic Peritonal Lavage, Blaisdell FW, Trunkey DD: Trauma Management (1) Abdominal Trauma, New York, Thime-Stratton, 1982, p45-48

19) Hubbard SG, Biuins BA, Sachatello CR, et al: Diagnostic errors in peritoneal lavage in patients with pelvic fructures. Arch Surg 114 : $844-846,1979$

20) Powell RW, Green JBM, Ochsner MG, et al : Peritoneal lavage in pediatric patients sustaing blunt abdominal trauma: A reappraisal. J Trauma $27: 6-10,1987$

21）合光秀磨，花野祥子，益田美也子他：下部消化管穿 孔一初期治㞠としての腹腔内大量洗浄を中心に 一, 救急医学 5:494-504, 1981

22) Thadepalli H, Lou MA, Bach VT, et al: Microflola of the human small intestine. Am J Surg $138: 845-849,1979$

23) Plant AG, Golbacle SL, Nahas L, et al: Studies of intestinal microflola. Gastroenter. ology $53: 868-871,1967$

24）北野光秀，山本修三, 茂木正寿他: 外傷性消化管破 裂，臨外 $42: 299-305,1987$

25）加来信雄：小腸損愎, 腹部外倥の実際. 加来信雄, 医学畫院, 東京, 1985, p167-172

26) Price J : Surgical interuention in case of general peritonitis. Prae. Philadelphia, Canthy M $26: 192-197,1905$

27）并口 橴：急性化膿性腹膜炎一特に穿孔性腹膜炎 の治療を中心として一, 外科診療 $5: 11-17$, 1963

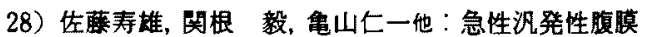
炎一外科的治療とその問題点を中心に一, 外科治 療 $38: 575-582,1978$

29）木村恒人：沉発性腹膜炎手術時における腹腔内大 量洗净法, 救急医学 $2: 807,1978$

30) Raves JJ, Slikin M, Diamiond DC: A bacteriologic study comparing closed suction and simple condict drain. Am J Surg 148: 618-620, 1984

31）渡辺 晃：腹腔内洗浄之合併化学㞠法の意義, 臨 外 $28: 1057-1062 ， 1973$

32) Baker CC, Oppenheimer L, Stephen B: Epidemiology of trauma death. Am J Surg 140: $144-150,1980$ 


\title{
CIINICAL STUDY OF TRAUMATIC SMALL INTESTINAL INJURIES
}

\author{
Katsuhiko SUGIMOTO, Kazuhiko MAEKAWA, Hisashi IMAI, Takashi OHWADA, \\ Seiichi SHIMAZU* and Kouichi ASO* \\ Department of Emergency \& Critical Care Medicine, Kitasato University \\ *Department of Surgery, School of Medicine, Kitasato University
}

\begin{abstract}
Seventy-four cases of traumatic small intestinal injuries treated at the Kitasato University Hospital Emergency Center and Department of Surgery were reviewed. More than half of these patients were victims of motor vehicle accidents and had multisystem injuries. Diagnostic difficulty was encountered among the patients with an impared level of consciousnes and/or associated remote injuries which may distract the clinician from the abdomen. Plain films of the abdomen, ultrasonography and computed tomography were of limited diagnostic value for traumatic small intestinal injuries. Diagnostic peritoneal lavage was a useful method for multisystem injury patients presenting with insignificant abdominal signs. The mortality rate is only $1.4 \%$, but the postoperative complication rate remains in the region of $40 \%$. One of the significant factors contributing to complications is delay in treatment.
\end{abstract}

